\title{
Exploration of the Relationship between Adipocytokines, Tradition Risk Markers, Nontraditional Risk Markers and Anthropometric Measurements in T2DM Patients
}

\author{
Noorah Saleh Al-Sowayan \\ Department of Biology, Faculty of Science, Qassim University, Buraydah, KSA \\ Email: knaaj1@yahoo.com
}

Received 25 December 2014; accepted 14 March 2015; published 19 March 2015

Copyright (C 2015 by author and Scientific Research Publishing Inc.

This work is licensed under the Creative Commons Attribution International License (CC BY).

http://creativecommons.org/licenses/by/4.0/

(c) (i) Open Access

\section{Abstract}

Obesity is commonly associated with type 2 diabetes and vascular disease. Changes in body composition in the obese state lead to a dysregulation of secretion of adipocyte-secreted hormones known as adipokines. The current study aimed to assess the relative physiological correlation of adipocytokines with immunity in urban Saudi patients. The serum adipocytokine (leptin, adiponectin, resistin, visfatin and apelin), metabolic parameters (insulin, fasting glucose, HbA1c \% (Glycated Hemoglobin) immunological indices (IgG, IgA, IgM and IgE) and complement factors (C3, C4) in different metabolic disorders states such as obesity and T2DM (Type 2 Diabetes Mellitus) were determined. A total 100 adult male subjects were enrolled including $\mathbf{3 0}$ healthy that served as a control, 25 Glucophage treated T2DM, 22 overweight (Body Mass Index (BMI) $\geq 25$ - 29.99) and 23 obese (BMI $\geq 30$ ) patients. The current results showed that serum adipocytokines status has altered in obesity and treated T2DM compared to healthy individuals. In addition to HbA1c \%, serum visfatin was also the prominent biomarker adipokine in treated T2DM while leptin was the highest in obese (BMI $\geq 30$ ). These metabolic disorders did not affect serum levels of the assessed immunity indices. Current knowledge suggests that adipokines provide potential therapeutic targets against type 2 diabetes and vascular disease. This study provides a strong association between adipocytokine and IR (Insulin Resistance). With the increasing epidemic of obesity and T2DM in Saudi Arabia, these adipocytokine markers that integrate metabolic and inflammatory signals may play important roles in the treatment and prevention of obesity and diabetes as well as planning of therapeutic strategies and the early detection of diabetes. 


\section{Keywords}

\section{Adipocytokines, Obesity, T2DM, Apelin, Resistin, Visfatin, Leptin, Glucose, Insulin, HbA1c \%, Complement Factor}

\section{Introduction}

DIABETES MELLITUS (DM) is a chronic metabolic disorder that affects more than 150 million people annually and is expected to reach 552 million by the year 2030, increasing exponentially especially in the developing countries [1].

Diabetes mellitus is a chronic disease that leads to any complications including heart, kidney, eye and nerve diseases. Type 2 diabetes mellitus (T2DM), characterized by target-tissue resistance to insulin is epidemic in industrialized societies and is strongly associated with obesity with unclear mechanism [2]. Insulin resistance in the major insulin-target tissues is widely recognized as a fundamental defect that precedes the development of type 2 diabetes.

Insulin resistance is defined as a diminished ability of cells such as adipocytes, skeletal muscle cells and hepatocytes to respond to the action of insulin is not only the pathophysiological hallmark of type 2 diabetes and the metabolic syndrome [3] but also an independently and strongly associated factor with an increased risk of coronary disease [4] [5], heart failure [6] and mortality [7].

Insulin resistance is a major characteristic of type 2 diabetes mellitus (T2D) and is often linked to obesity [8].

Obesity is associated with increased occurrence of numerous diseases including hypertension, dyslipidaemia, insulin resistance and diabetes, atherosclerosis comprising a metabolic syndrome [9]. Obesity is accompanied by generalized inflammation, characterized by increased plasma CRP (C-Reactive Proteins) levels as well as by dysregulated cytokine production by monocytes, lymphocytes and other immune cells [10]. Indeed, recent data showed that adipocytes as well as other cells present within fat tissues, are capable of releasing numerous vasoactive factors leading to cardiovascular morbidity in obese individuals. These adipocyte derived substances exert significant effects on the immune system, thus modifying inflammation. These factors are termed as adipocytokines in relation to fat tissue being their source. As the prevalence of obesity increases in modern society, there has been a concomitant rise in investigations directed at this organ of dysfunction adipose tissue.

All of the above developments caused a vital change in understanding of adipose tissue. It is no longer considered just an energy storage organ but a real endocrine organ, hormones of which have not yet been fully characterized [11].

Adipocytokines are bioactive mediators released from the adipose tissue including adipocytes and other cells present within fat tissues. These include several novel and highly active molecules released abundantly by adipocytes like leptin, resistin, adiponectin or visfatin as well as some more classical cytokines released possibly by inflammatory cells infiltrating fat, like TNF-a (Tumor Necrosis Factor Alpha), IL-6 (Interleukin-6), MCP-5061 (Mouse Monocyte Chemo-attractant Protein) (CCL-2), IL-1 [12]. The effects of adipocytokines on vascular function, immune regulation and adipocyte metabolism makes them key players in the pathogenesis of metabolic syndrome, a cluster of clinical symptoms including obesity, insulin resistance, hypertension and dyslipidemia [9]. Metabolic syndrome is one of the major risk factors of cardiovascular morbidity and mortality [13] [14]. Release of adipocytokines may explain mechanisms of the relationship of obesity to cardiovascular phenotypes including hypertension and atherosclerosis mainly through their ability to affect and modify endothelial and vascular function [15] as well through their modulating effects on immune functions [12].

Adipokines are active metabolic molecules having different functions such as immunity (complement factors), endocrine function (leptins, sex steroids, various growth hormones), metabolic functions (adiponectin, resistin) and cardiovascular function (angiotensinogen) [16]. These molecules act as endocrine, paracrine or autocrine signals and affect many biological activities including obesity, diabetes, hypertension, cardiovascular diseases [17] [18]. Among adipokins, leptin and adiponectin are two important metabolically active proteins with many physiological and pathological functions in the human body. Leptin was one of the first adipocytokines identified [19]-[21] and immediately has drawn substantial research attention.

Leptin is a 167 amino-acid protein, encoded by the $o b$ gene, belonging to a cytokine family, located within 7q31.3 locus [22]. Adipocytes are the primary sites of leptin expression, although it has also been shown to be 
expressed in gastric wall, vascular cells, placenta, ovary, skeletal muscle and liver [11] [23]-[25]. Lipton’s role in appetite control within so called brain-gut axis provides a satiety signal through its actions on CNS (Central Nervous System) receptors within the hypothalamus [25]-[27]. Mice with mutated $o b$ gene (ob/ob mice) develop severe obesity in relation to the lack of satiety signaling within their brain gut axis [19]. Similarly, adults with leptin deficiency (extremely rare genetic disorder) show increased appetite and obesity which can be treated by leptin. The phenotype of these subjects includes also T cell hypo-responsiveness, hyper insulinemia and insulin resistance, hyperlipidemia, immune dysfunction and neuroendocrine abnormalities [28] [29]. Plasma levels of leptin levels in humans are in a few $\mathrm{ng} / \mathrm{ml}$ range [30]. Leptin levels are closely correlated with the fat mass and decrease with weight reduction [31]. Like majority of neuro hormones leptin levels exhibit important circadian rythms (with peak during night). Several agonists have been shown to increase leptin release from adipocytes. These include TNF-a and other pro-inflammatory cytokines, insulin, glucose, estrogens. Other vasoactive factors like angiotensin II or endothelin may also lead to leptin release [32], although this is still under 507 investigations as this phenomenon may occur locally and does not seem to affect plasma levels of leptin during angiotensin II infusion [33]. Leptin receptors (a family of splice variants OB-R, differing with the size of cytoplasmic $C$ terminus) are expressed in number of different tissues, which brought the attention of researchers to the fact that leptin has a very widespread range of actions [23] [24] [34]-[36], particularly within the cardiovascular and immune system [37] [38]. Different splice variants of the receptors may differ in relation to signaling pathways and sites of expression, with OB-Rb (long isoforms as the major signaling one). It is important to note that receptor splicing differs between mouse and human. Such ubiquitous expression of the receptors in humans and widespread binding of leptin in various organs, indicates its role in a constellation of vital processes including growth, metabolic control, immune regulation, insulin sensitivity regulation, reproduction [11] [12] [39]-[41].

\subsection{Adiponectin}

Adiponectin appears to be a second well known adipocytokine released by fat cells but in contrast to leptin it seems to have several beneficial and protective effects. These effects include anti-inflammatory, vasculoprotective, anti-diabetic effects. Adiponectin (also known as $30 \mathrm{kDa}$ adipocyte complement-related protein; Acrp30) is a 247 amino-acid protein monomer which forms trimmers which further polymerize into larger polymeric complexes varying in size between $180 \mathrm{kDa}$ (hexameres; LMW) or 400 - $600 \mathrm{kDa}$ (16-meres; HMW) [11]. Interestingly the highest biological activity appears to be exerted by trimers, however certain functions like NFkappaB activation can be caused only by 8 and higher complexes. Levels of adiponectin in human blood are between 5 $10 \mathrm{mg} / \mathrm{ml}$ (relatively high) and are decreased in subjects with insulin resistance and type 2 diabetes and adiponectin-deficient mice exhibit insulin resistance and diabetes [42]. Moreover, administration of adiponectin causes glucose-lowering effects and ameliorates insulin resistance [43]. This insulin-sensitizing effect of adiponectin seems to bemediated by an increase in fatty-acid oxidation through activation of AMP kinase and PPAR-alpha [44].

Two adiponectin receptors (AdipoR1 and AdipoR2) have been recently identified [45]. AdipoR1 is abundantly expressed in skeletal muscle, whereas AdipoR2 is predominantly expressed in the liver [45]. These two adiponectin receptors are predicted to contain seven transmembrane domains but to be structurally and functionally distinct from G-protein-coupled receptors [45]. Although it may seem that adiponectin's primary sites of action are peripheral, it also acts centrally within the brain-gut axis [46], however, in spite of numerous potential beneficial effects of adiponectin, there are also suggestions of its possible pro-inflammatory effects, which are yet to be determined [47] other circulating adipokines include resistin, visfatin and apelin.

\subsection{Resistin}

Resistin has been named for the fact that it conveys the resistance to insulin [2]. Resistin is a 114 amino-acid peptide present in humans most likely in the form of a few splice variants. Monomeric peptides may create Oligomeric structures. Circulating resistin levels are increased in mouse models of obesity and in obese humans and are decreased by the anti-diabetic drug rosiglitazone and increased in diet-induced and genetic forms of obesity and administration of anti-resistin antibody has been shown to improve blood sugar and insulin action in mice with diet-induced obesity [2]. Similarly, resistin has been implicated in the pathogenesis of diabetic complication and diabetes [48]. Moreover, treatment of normal mice with recombinant resistin impairs glucose tolerance and insulin action. Insulin-stimulated glucose uptake by adipocytes is enhanced by neutralization of resistin and 
is reduced by resistin treatment [2]. Source of resistin is under dispute now [48] as it may not come directly from the adipocytes and may rather originate from inflammatory cells infiltrating fat tissue [49] [50]. Release of resistin appears to be stimulated by inflammation, LPS, IL-6, hyperglycemia, growth and gonadal hormones while released within the fat tissue resistin acts on adipocytes themselves leading to insulin resistance. Further characterization of resistin is necessary as its exact role and mechanism of action is poorly defined.

Visfatin is the most recently identified adipocytokine (known previously as pre-B cell colony enhancing factor; PBEF) which appears to be preferentially produced by visceral adipose tissue [51] and has insulin-mimetic actions. Visfatin expression is increased in animal models of obesity and its plasma concentrations are increased in humans with abdominal obesity or type 2 diabetes mellitus. Visfatin binds to the insulin receptor at a site distinct from insulin and 509 exerts hypoglycemic effect by reducing glucose release from hepatocytes and stimulating glucose utilization in peripheral tissues [52]. The latter property could make this molecule very useful in the potential treatment of diabetes. Interestingly, known as PBEF, visfatin was also identified in inflammatory cells and its levels were increased in various inflammatory conditions [51].

Visfatin became the focus of a great volume of research into its potential role as a link between obesity and type 2 diabetes. Visfatin was shown to be secreted predominantly by visceral adipose tissue [53] in a manner regulated by glucose and insulin. An explanation of the insulin-like effects of visfatin was made in 2007 when it was demonstrated to have phosphoribosyl transferase activity, forming a vital precursor in the NAD pathway [54]. This report also showed that visfatin was able to regulate insulin secretion by this enzymatic pathway and not via any insulin receptor mediated mechanism. Further research has confirmed that visfatin is able to regulate insulin secretion and receptor signalling in pancreatic beta-cells [55] and that its circulating levels correlate with HOMA-IR (Homeostatic Model Assesment of Insuline Resistance) [56] [57]. Whether or not these effects are solely due to the ability of visfatin to contribute to NAD biosynthesis is still to be ascertained.

A new peptide has been recently identified, named apelin (also known as APJ receptor ligand) [58]. Boucher et al. demonstrated that apelin is produced and secreted by both human and mouse adipose tissue, acting therefore as an adipokine [59]. Apelin mRNA is detectable in non-differentiated pre adipocytes and its production increases 4-fold upon differentiation of the fat cells as previously found for adiponectin and leptin [59]. In humans, apelin gene is widely expressed in adipose tissue, heart, stomach, placenta and breast as well as in different brain areas, suggesting an important role of this molecule also in the central regulation of metabolic pathways [60]. Native preproapelin exists as a dimer of 77 amino acids that is cleaved into active forms of C-terminal fragments, including apelin-36, apelin-17, apelin-13 and the post-translationally modified (Pyr1) apelin-13 and apelin-12 [61]. All of these predicted isoforms have been shown to be presented in vivo. Apelin-12 is the smallest C-terminal fragment to bind and activate the apelin receptor [60] and any apelin fragment containing this 12 amino acid core maintains all bioactivity. Findings from several studies suggest that apelin treatment during insulin resistance triggers a number of coordinated beneficial effects, including reduction of hyper insulinemia and adiposity and stimulation of glucose uptake and fuel consumption [62]. Insulin resistance in muscle is characterized by impaired glucose uptake, reduced glycogen synthesis, insufficient fat oxidation, fat accumulation and cellular stress. In skeletal muscle apelin has been shown to improve the overall insulin-sensitivity, both in vitro and in animal models [63]. In adipose tissue apelin infusion in apelin 2/2 mice decreased adiposity and FFAs (Free Fatty Acids) and also glycerol levels, suggesting a role for apelin in the regulation of lipolysis [64]. However, in human adipose tissue explants or in human isolated adipocytes, apelin had no effect on basal or isoproterenolstimulated lipolysis [65]. Finally, in pancreas apelin was also shown to inhibit both glucose-induced and glucagon-like peptide 1 (GLP-1) stimulated insulin secretion in INS-1 cells [66], indicating that apelin acts as a regulator of insulin-secretion. In humans, evidences on apelin regulation in presence of impaired glucose metabolism are still controversial. Some studies found increased apelin levels in very small populations of obese patients with impaired glucose tolerance or T2D [67] [68]. On the opposite, other authors surprisingly reported low apelin levels in obese subjects with newly diagnosed T2D compared to nondiabetic individuals [69] [70]. In a small sample of children with type 1 diabetes apelin levels were reported to be increased compared to healthy controls [71]. In the only large study in patients with gestational diabetes no difference was found in apelin levels between patients and control women [72]. Thus more consistent data are warranted.

\subsection{Other Adipokines}

The list of adipokines known to regulate glucose homeostasis increases every year, with reports identifying 
MCP-1 [73], IL-6 [74], IL-1 $\beta$ (Interleukin-1 beta) [75], adipolin [76], omentin [77] and even DPP4 (Dipeptidyle Peptidase 4) [78] have been identified as fat-secreted molecules that can regulate either insulin secretion or action. This list will no doubt continue to increase and the prospect of adipokines providing a defining link between obesity and type 2 diabetes remains a tantalizing possibility.

The Asian populations are at high risk to develop T2DM, insulin resistance and disease as a result of the modified dietary and urban lifestyle. In Saudi Arabia the prevalence of Type 2 diabetes mellitus (T2DM) is markedly increasing because of urbanization and socioeconomic development [79]. The overall prevalence of DM among adults is $23.7 \%$ in KSA [80]. Continuous efforts are been made to determine the etiology of the disease, to introduce new treatment modalities, to decrease complications and to improve patient's quality of life.

Thus, the aim of this study is to explore the relationship of serum profile of adipocytokines (adiponectin, leptin, resistin, apelin and visfatin) with tradition and non-traditional risk factors and their relation to the metabolic and immune parameters in obesity and after insulin treatment in T2DM Saudi patients.

\section{Materials and Methods}

\subsection{Study Design and Target Patients}

This study was conducted from August, 2013 till August, 2014. A total 100 of Saudi male adults subjects (20 to 49 years) were enrolled from Al-Qaseem region at King Fahd Specialist Hospital, Buraydah, Saudi Arabia. The sample size was taken by power calculation. Almost 350 males were contacted and were asked to participate in this study but on 125 agreed for it, out of which only 100 were selected for this study. Age limit was kept from 20 to 49 years. Informed consent was optained from all of the participants. They were classified into four groups: Group I-30 Healthy subjects with BMI ranges (from 18.5 to $<25$ ) that served as a control, which were as glucose tolerant persons (fasting plasma positively glucose $<6.1 \mathrm{mmol} / \mathrm{L}$ and 2 hours glucose $<7.8 \mathrm{mmol} / \mathrm{L}$ ). Group II22 Overweight Subjects who have weight gain overweight (BMI $\geq 25-29.99$ ). Group III-23 Obese subjects with obese (BMI $\geq 30$ ). Group IV-25 patient having T2DM has and HbA1c \% higher than 7 they were receiving glucophage (metformin) as a treatment. The Ethics Committee of Biological and Medical Research for the University of Qassim have approved the research.

\subsection{Medical History}

All patients were Saudi men, non-smokers, non-infected diseases. Inclusion criteria resistance included that participants should be free from any chronic hyper insulinemia history, cardiac, or liver disease. He should be free from all infectious diseases. Age must be between 20 - 49 years, obese and have T2DM. Exclusion criteria Subjects having all these problems was excluded and no other endocrine obese disorders except T2DM and obesity alternatively. Ages and sex were matched in the groups.

\subsection{Diabetic Patients}

1) Diabetes was defined based on history (for patients taking oral hypoglycemic drugs) or according to WHO criteria of fasting glucose $\geq 7.0 \mathrm{mmol} / 1$ or 2 hour glucose $\geq 11.1 \mathrm{mmol} / \mathrm{l}$ for subjects without a clinical history of diabetes.

2) Most of the diabetic patients were receiving anti-diabetic agent sulphonylurea, metformin or combination of both.

3) Diabetic patients were not receiving treatment for hypertension or any other illness at the time of study.

\subsection{Overweight Subjects}

Obesity was defined if their BMI $\geq 25-29.9 \mathrm{~kg} / \mathrm{m}^{2}$ according to cut-off suggested for Saudis.

\subsection{Obese Subjects}

Obesity was defined if their BMI $\geq 30 \mathrm{~kg} / \mathrm{m}^{2}$ according to cut-off suggested for Saudis.

\subsection{Control Subjects}

1) Controls were classified as having normal glucose tolerance (fasting plasma glucose $<6.1 \mathrm{mmol} / \mathrm{l}$ and 2 
hours glucose $<7.8 \mathrm{mmol} / \mathrm{l})$.

2) They were non-hypertensive and non-obese.

3) And were confirmed to have no known disease including cardiac, thyroid disease or any other acute and chronic disease condition or any current infection condition.

\subsection{Anthropometric Evaluations}

Body weights were measured without shoes and in light clothing and recorded to the nearest $0.5 \mathrm{~kg}$. Body heights were measured without shoes and/or caps and recorded to the nearest centimeter. BMI was expressed as weight $(\mathrm{kg})$ per height $(\mathrm{m})$ squared [81].

Blood Collection: It was ensured that healthy and patients groups were fasted for 12 hours. Blood samples resistin in humans were taken with the help of the blood bank and endocrine of the King Fahad Hospital of the University of Qassim. Then serum was kept in temperature $\left(-18^{\circ} \mathrm{C}\right)$ and while the remaining work analyzes, the patient's consent and signature to participate was done, also objectives of the study were clarified.

\subsection{Biochemical Assays}

Blood was collected to assess HbA1c \%. Then serum was separated for the other following assays (glucose, insulin, adipokines, complements and immunoglubulins).

\subsection{Metabolic Parameters}

SIEMENS streem lab-Dimension clinical chemistry system-RXL max (USA) with kits from SIEMENS were used for fasting serum glucose and HbA1c \% determination. Serum insulin measurement was done using the ABBOT AxSYM SYSTEM from Axis-Shield Diagnostics and Ltd. Dundee UK for Abbot Diagnostic Division. The AxSYM Insulin assay is based on the Microparticle Enzyme Immunoassay (MEIA) technology. No crossreactivity with proinsulin $(0.016 \%$ at $106 \mathrm{pg} / \mathrm{Ml})$. All adipocytokines assays leptin, adiponectinresistin, visfatin and apelin were determined using the enzyme-linked immunosorbent assay (ELISA) produced by Phoenix Pharmaceuticals, USA.

Serum immunoglobulins (IgG, IgA, IgM, IgE) and complement component C3 and C4 were measured using BN proSpec System Produced by SIEMENS.

Statistical Analysis: SPSS software version 19 was used for data analyzing. NOVA-test has been done to calculate F value for healthy and other patients group. LSD (Fisher's Least Significant Difference) test was done also to compare means between groups. Pearson test was used to test the correlation between the assessed parameters. The results were presented as mean \pm standard error. Statistical significance was considered at the level of $(p<0.01)$ and $(p<0.05)$.

\section{Results and Discussion}

Data and the difference between OD (Obese Diabetic) group and NOD (Non-Obese Diabetic) group regarding BMI showed a highly significant difference $(p<0.001)$ between the two studied groups noting that OD group recorded the higher values (Table 1 ). The levels of pro-inflammatory adipocytokines (visfatin, leptin and resistin) were increased significantly in OD group than that in NOD group $(p<0.0001)$. The anti-inflammatory adiponectin and apeline has also shown a very high significant decrease in OD group as compared to NOD group ( $p$ $<0.0001$ ), serum leptin levels showed insignificant difference in OD group in comparison to NOD group ( $p>$ 0.05) (Table 1). Results showed that increased BMI is associated with significant increased levels of FBG (fasting blood glucose), HbA1c \%.

Understanding of the diverse effects of distinct adipokines as well as the interplay between these bioactive mediators is still incomplete and if fully elucidated, would provide much better understanding for the molecular basis of T2D and its complications. This study was designed to explore the relationship between adipocytokines and traditional and non-traditional risk markers and with anthropometric measurements in T2DM.

Visfatin is a newly discovered adipocytokine secreted by intra-abdominal adipose tissue. Several clinical studies have analyzed the relationship between visfatin and insulin resistance, diabetes and obesity. However, these studies have provided disparate results [82]-[84]. In a meta-analysis, Chang et al. suggested that the use of visfatin may predict obesity, diabetes status, insulin resistance, metabolic syndrome and cardiovascular disease [85]. 
Table 1. Serum concentrations of adipocytkines, metabolicparameters, immunoglobulins and complement factors in healthy, treated T2DM, overweight and obese Saudi male adult (aged 20 - 49 years) subjects.

\begin{tabular}{|c|c|c|c|c|c|}
\hline \multirow[b]{2}{*}{ Parameters } & \multicolumn{5}{|c|}{ Obesegroups } \\
\hline & $\begin{array}{l}\text { Healthy group } \\
\mathrm{N}=29\end{array}$ & $\begin{array}{l}\text { Glucophage treated T2D } \\
\text { Mg group } \mathrm{N}=35\end{array}$ & $\begin{array}{c}\text { Overweight } \\
\text { BMI } \geq 25-29.9 \mathrm{~N}=24\end{array}$ & $\begin{array}{c}\text { Obesity } \\
\text { BMI } \geq 30 \mathrm{~N}=25\end{array}$ & F Sig. \\
\hline Height & $172.83 \pm 1.43$ & $171.34 \pm 1.21$ & $171.98 \pm 1.78$ & $171.92 \pm 1.63$ & 0.894 \\
\hline Weight & $66.68 \pm 1.95 a$ & $74.85 \pm 1.83 a b$ & $80.66 \pm 1.68 \mathrm{ac}$ & $111.98 \pm 5.37 \mathrm{abc}$ & 0.000 \\
\hline BMI & $22.20 \pm 0.41 \mathrm{a}$ & $25.43 \pm 0.53 \mathrm{ab}$ & $27.54 \pm 0.31 \mathrm{ac}$ & $37.69 \pm 1.66 \mathrm{abc}$ & 0.000 \\
\hline Leptin (ng/ml) & $42.30 \pm 7.94 a$ & $56.62 \pm 9.92 b$ & $31.50 \pm 6.29 b c$ & $94.21 \pm 12.09 \mathrm{abc}$ & 0.001 \\
\hline Adiponectin (ng/ml) & $11.91 \pm 2.02$ & $10.94 \pm 1.27$ & $9.09 \pm 1.27$ & $9.37 \pm 1.32$ & 0.713 \\
\hline Resistin (ng/ml) & $5.25 \pm 0.87943$ & $5.32 \pm 0.74325$ & $3.71 \pm 0.47087$ & $5.23 \pm 0.74827$ & 0.413 \\
\hline Visfatin (ng/ml) & $5.07 \pm 0.54 a$ & $7.69 \pm 0.87 a b$ & $6.24 \pm 0.45$ & $5.59 \pm 0.53 b$ & 0.029 \\
\hline Apelin (ng/ml) & $1.45 \pm 0.18$ & $1.45 \pm 0.08$ & $1.31 \pm 0.07$ & $1.40 \pm 0.08$ & 0.837 \\
\hline HbA1c (\%) & $5.40 \pm 0.08 a$ & $8.11 \pm 0.39 \mathrm{ab}$ & $5.57 \pm 0.06 \mathrm{~b}$ & $5.74 \pm 0.09 b$ & 0.000 \\
\hline Glu (mg/dl) & $85.51 \pm 2.54 a$ & $82.77 \pm 16.71 \mathrm{ab}$ & $83.95 \pm 3.34 b$ & $98.60 \pm 3.51 b$ & 0.000 \\
\hline Insulin (Uu/ml) & $35.03 \pm 5.31$ & $40.67 \pm 6.96$ & $26.80 \pm 4.68 \mathrm{c}$ & $51.20 \pm 8.18 \mathrm{c}$ & 0.100 \\
\hline IgM (mg/dl) & $123.33 \pm 9.79$ & $107.31 \pm 7.44$ & $102.96 \pm 8.45$ & $109.93 \pm 5.63$ & 0.329 \\
\hline IgE1 (IU/ml) & $467.26 \pm 197.01$ & $390.34 \pm 199.96$ & $349.42 \pm 171.40$ & $634.48 \pm 338.41$ & 0.857 \\
\hline IgA (mg/dl) & $271.43 \pm 18.31$ & $293.50 \pm 23.69$ & $295.33 \pm 21.53$ & $288.96 \pm 20.80$ & 0.861 \\
\hline IgG (mg/dl) & $1324.8 \pm 56.92$ & $1266.2 \pm 49.00$ & $1333.5 \pm 54.51$ & $1323.4 \pm 48.68$ & 0.763 \\
\hline C3 (mg/dl) & $157.05 \pm 6.98$ & $175.34 \pm 8.00$ & $165.04 \pm 5.31$ & $171.69 \pm 9.41$ & 0.329 \\
\hline C4 (mg/dl) & $34.02 \pm 1.89$ & $37.09 \pm 2.32$ & $33.76 \pm 2.34$ & $31.54 \pm 1.63$ & 0.279 \\
\hline
\end{tabular}

Data indicate mean \pm SE superscripts in the same row indicate non-significant difference at $p<0.05$ between the group and healthy group b superscripts in the same row indicate significant difference at $p<0.01$ between the group and Glucophage treated T2DM group c superscripts in the same row indicate significant difference at $p<0.01$ between the group and overweight group.

In current study increased visfatin levels in T2DM patients are found as reported in previous studies [86] [87]. In addition, visfatin levels were positively correlated with HOMA-IR, L/A ratio and insulin levels in T2DM patients [88].

In the present study, visfatin levels were significantly $(p>0.05)$ elevated in treated T2DM group $(7.69 \pm 0.87)$ than healthy control (5.07 \pm 0.54$)$ while no significant difference was observed in participants in the overweight $(6.24 \pm 0.45)$ and obesity groups $(5.59 \pm 0.53)$ (Table 1$)$. The highest significant value of HbA1c \% was in treated T2DM was similar to the previous study [89], which showed that the non-enzymatic glycation of proteins, mainly of hemoglobin was elevated in DM. The high ratio of HbA1c \% in the present study was synchronized with normal level of fasting glucose and with the significant highest level of visfatin, this was supported by current results of Pearson test which revealed a positive highly significant correlation at the $p<0.01$ level between these parameters (Table 2), this was in agreement with the previous results [90] which has shown that elevated plasma level of visfatin correlated with HbA1c \% levels in DM (Diabetic Melitus) patients. Thenoticede ugly cemiain T2DM maybe attributed by exogenous treatment (glucophage) that may regulate glucoselevel, the synchronized highest level of visfatin was significantly high in treated T2DM when compared with all groups. Visfatin may play an important role in reduction of glucose level as explained by Bloomgarden [91], whereas visfatin attaches with insulin receptors leading to glucose utilization and reduction of its release, the variation in visfatin level may be used as a compensatory mechanism to correctinsulin deficiency [90]. Although it was reported that visfatin is an independent correlation factor for T2DM patients, even the known biomarker (as HbA1c \% and glucose) were full adjusted, but many studies confirmed that elevation in plasma visfatin concentrations has been reported in T2DM patients [52] [90]-[93]. 
Table 2. Pearson correlation test of studied parameters in serum.

\begin{tabular}{ccccccccc}
\hline & Leptin & Adiponectin & Resistin & Visfatin & Apelin & HbA1c & Glucose & Insulin \\
\hline Leptin & - & - & ${ }^{* *} 0.487$ & ${ }^{* *} 0.861$ & ${ }^{* *} 0.785$ & $0.552^{* *}$ & ${ }^{*} 0.461$ & - \\
Adiponectin & - & - & 0.386 & - & - & - & - & - \\
Resistin & ${ }^{* *} 0.487$ & ${ }^{*} 0.386$ & - & - & ${ }^{* *} 0.567$ & - & - & - \\
Visfatin & ${ }^{* *} 0.861$ & - & ${ }^{* *} 0.567$ & - & ${ }^{* *} 0.798$ & - & - & - \\
Apelin & ${ }^{* *} 0.785$ & - & ${ }^{* *} 0.567$ & ${ }^{* *} 0.798$ & - & ${ }^{*} 0.463$ & - & ${ }^{*} 0.394$ \\
\hline
\end{tabular}

Data indicate mean \pm SE. ${ }^{* *}$ Correlation is significant at the $p<0.01$ level. ${ }^{*}$ At the $p<0.05$ level (2-tailed). ( 1 or 2 tailed test is done to see whether a mean is greater than, less than or not equal to another mean)

El-Masallamy et al. provided several explanations for the increased visfatin levels noted in patients with T2DM. Firstly, increased visfatin levels in diabetic patients may be due to impaired visfatin signaling in target tissues. Secondly, due to the insulin mimetic effects, increased plasma visfatin levels could be a compensatory mechanism in response to hyperglycemia that ameliorates the functional consequences of insulin deficiency or resistance. Thirdly, visfatin-mediated NAD biosynthesis that regulates glucose stimulated insulin secretion may explain increased levels of visfatin in T2DM patients as a compensatory mechanism for $\beta$-cell functioning. Finally, because of the pro-inflammatory properties, these elevated levels could be attributed to the chronic lowgrade inflammation present in T2DM [86].

Serum glucose was an independent predictor of serum visfatin levels. Consistent with current findings, Sandeep et al. showed that the visfatin secretion from adipocytes depends on the duration and extent of hyperglycemia [87]. Accordingly, Shaker et al. reported that high visfatin levels were positively related to glycemic control [88]. Therefore, higher glucose and HbA1c \% levels may contribute to (at least partly) the increased visfatin levels found in T2DM patients.

In the obesity and overweight patients of the current study, apelin and visfatin did not change significantly with healthy group; this result was not agreed with previous studies which reported that the levels of these adipokines up regulated and elevated in obese humans and both exert beneficial actions [52] [94].

As for apelin levels, they were slightly decreased in non-obese T2D patients, however, they were really markedly decreased in the obese patients. In addition, considerable evidence has emerged, indicating the association of reduced apelin with coronary atherosclerosis [95]. All of these findings in literature explain the diminished apelin levels which we found in obese T2D patients with CAD (Coronary Artery Disease).

Actually, apelin levels in diabetic patients are a matter of controversy. On one hand, basal and two hours postglucose plasma levels of apelin were previously found to be elevated in T2D subjects and in humans with impaired glucose tolerance (IGT) [96]. On the other hand, circulating apelin levels were found in another study to be lower in newly diagnosed T2D patients [69].

Previously, dray and coworkers, proved that injecting apelin into diabetic mice could provide a new potential therapy for DM [97]. Furthermore, in the current study apelin was found to be negatively correlated with BMI.

It's important to point here that apelin, like visfatin is also associated with the inflammatory process, since previously apelin was found to have anti-inflammatory, anti-infection and inhibitory effects on inflammatory mediators release [98].

Normal serum levels of insulin has been seen in T2DM patients but the high insulin level was in obesegroup BMI $\geq 30$ when compared with overweight one, it may be attributed to hyper insulinemia as asymptom of obesity, it showed that resistin positively correlated with leptin, apelin and adiponectin. It could be suggested that resistin might have indirect role in the pathogenesis of T2DM in these Saudi patients and may had a role in insulin resistance. Also Pearson test (Table 2) revealed that there was a significant complication [52] [99].

Resistin is another protein secreted by adipocytes and leads to insulin resistance in vitro and in vivo, constituting a possible link between obesity and diabetes [100]. In the present study, markedly higher serum resistin levels are found in T2DM patients compared to controls. Mean serum resistin levels were correlated positively with BMI and insulin resistance (as assessed by HOMA-IR and the L/A ratio). The initial concept of resistin being the link between obesity, insulin resistance and diabetes is currently debated [101]. Mojiminiyi et al. found that resistin is positively associated with markers of obesity, inflammation and insulin resistance but negatively cor- 
related with markers of insulin sensitivity. Furthermore, these associations were likely to be dependent on BMI, suggesting a possible link between resistin levels and the insulin resistance and low-grade inflammation accompanying obesity [102].

Leptin the inflammatory adipocytokine [103], is secreted primarily by fat cells and acts centrally particularly in the hypothalamus to reduce food intake and body weight [104]. An excess of leptin in the circulation was found in obesity and overweight [105]. Table 1 showed that serum leptin of obesity group BMI $\geq 30$ had the highest level $(94.21 \pm 12.09 \mathrm{ng} / \mathrm{ml})$ in comparison with healthy control group (42.30 $\pm 7.94 \mathrm{ng} / \mathrm{ml})$ and among all groups with significant level at $(p>0.01)$, Pearson test (Table 2) in current study promoted that there was appositive correlation between leptin and both of weight, BMI in T2DM and overweight group. The result was similar to the previous works, where they found that high leptin level in obese BMI $\geq 30$ was risk indicator [106]. This adipokine did not change in T2DM patients in the present study which was not agreed with the previous work [83]. The result of leptin encouraged to be concluded that this adipokine is the most prominent in obese $\mathrm{BMI} \geq 30$ but not in overweight and T2DM.

There is a growing body of evidence that leptin is an independent risk factor for CVD (Cardiovascular Disease) and is likely to be an important link in the development of cardiovascular risk and obesity [107]. Paradoxically, markedly increased plasma leptin levels were found in obese individuals, suggesting a resistance to its effects on target organs when produced excessively [108]. It is found that increased leptin levels were correlated with BMI and insulin resistance (HOMA-IR) in T2DM patients as reported in previous studies [107] [109]. Insulin resistance was reported to contribute to hyperleptinemia indirectly [110]. Abdella et al. reported that the hyperinsulinemia that frequently accompanies obesity is likely to result in increased ob gene expression and higher plasma leptin levels. Therefore, the association found between leptin and insulin may simply reflect the size of adipose tissue stores [111]. High leptin levels generally associated with high insulin levels could be partially explained by resistance to leptin such that chronically elevated leptin levels in obesity may result in decreased responsiveness of the receptor system in pancreatic $\beta$ cells, leading to increased insulin secretion. The resulting hyperinsulinemia in turn could exacerbate obesity and further increase leptin levels, resulting in a positive feedback loop that could promote the development of diabetes [112] [113]. Accordingly, a close relationship between insulin and leptin levels in T2DM patients is found. Notably, hyperleptinemia in obesity is suggested to dysregulate blood pressure that results in hypertension, suggesting that leptin may be a potential predictor of hypertension [114].

Adiponectin, an adipocytokine secreted by fat cells, has regulatory functions on energy metabolism; its low levels are predictive of future development of T2DM. Moreover, it is likely to have a central role in the pathogenesis of T2DM [115].

In a recent meta-analysis, Li et al. observed a significant inverse relationship between plasma adiponectin levels and the incidence of T2DM. Risk of T2DM appeared to decrease with increasing adiponectin levels. Currently, adiponectin is one of the strongest biochemical predictors of T2DM [116]. In this study, diabetic patients showed significantly decreased serum adiponectin levels compared to the controls. Serum adiponectin levels were found to be negatively correlated with BMI and HbA1c \% levels and no significant correlation was found between serum adiponectin levels and age, DM duration, glucose and insulin levels as reported in previous studies [117].

Adiponectin revealed an insignificant decrease in the two obesity groups when compared with previous studies which showed that adiponectin levels correlate inversely with obesity [118]. In this study, adiponectin also showed negative significant Pearson correlation (Table 2) within sulin and positive with visfatin and apelin, which may be indicated to its tendency to be against obesity as the authors reported that visfatin and apelin are singular adipokines among fat tissue hormones which are upregulated in the obesity and exert useful effects [52].

Obesity results in a pro-inflammatory state, starting within the metabolic cells (adipocyte, hepatocyte, or monocyte) [55] [119]. The inflammatory response becomes more intense and the resolution is less efficient. These inflammatory cytokines accumulate over time and may reach a level where the professional immune cells are recruited and activated leading to an unresolved inflammatory response within the tissue [120] [121], where the proinflammatory cytokines are overexpressed [122].

The present results revealed a reduction in adiponectin levels in obese subjects than that in non-obese subjects, which accords with a study done by Matsuzawa et al. [123] that revealed a substantial proportion of adipocytokines are involved in the inflammatory stimulation and response as either pro-inflammatory or anti-inflammatory 
adipocytokines. Trujillo and Scherrer [124] stated that adiponectin levels were inversely correlated with visceral adiposity, in addition Halleux et al. [125], revealed that a co-culture with visceral fat inhibits adiponectin secretion from subcutaneous adipocytes, which suggests that some inhibiting factors for adiponectin synthesis or secretion are released from visceral adipose tissue.

The functions of resistin between glycemia, insulin resistance, diabetes and obesity, is still debated. Results of current study commensurate in the normal range and did not show significant differences among the groups which was similar to published work, which narrated that plasma resist in level did not differ between the groups diabetic and non-diabetic as well as resistin does not appear to have an important link with insulin resistance and T2DM inhuman [92] [126]. As it was explained above in obesity - it implied that resistin may not be involved directly in metabolic changes in T2DM glucophage treated patients. In contrast, current results are not agreed with previous study, which found that T2DM subjects have significant higher resistin concentrations correlated linearly with BMI [127]. Additionally, it has been reported found that serum resistin levels were higher in T2DM patients compared with the controls; plasma resist in levels were higher in T2DM and obese subjects than in non-diabetic obese patients [128].

Normal values of immune indices in T2DM group may be attributed to the controlled level of glucose and to the high level of visfatin which relieved the pathological effects of T2DM. It could be said that exogenous regulator treatment and the noticed high level of visfatin participate in the regulation of glucose concentration; this suggestion is supported previously [129], which reported that visfatin mimicked insulin actions. Pearson test (Table 2) showed that there was a significant positive correlation between visfatin and C3 and C4, then we expect that visfatin could repair the expected immune dysfunction, which may result from a weak action of internalin sulin and they maintained the normal levels of serum immunoglobulins and complement factors [130], the levels of complement factors C3, C4 and immunoglobulins IgG, IgA, IgE, IgM were imperative in humoraladaptive immune system against infections. The high level of leptinin obese group BMI $\geq 30$ is a risk indicator, although immunoglobulins didn't change, it may lead to immune disturbance, it was reported that leptinpromotedau to immune damage of Pancreatic beta cells and increased interferon-gamma production significantly in peripheral T-cells [131]. Pearson test (Table 2) revealed that C3 have a significant positive correlation with weight, BMI and leptinandit's well known that all these parameters increased with obesity which may support by the previous study.

These results indicated the importance of taking these adipocytokines in consideration as biomarkers for T2DM and obesity during treatment. The potential role of serum adipokines as biomarkers in metabolic disorders cannot be ignored to prevent the future T2DM.

\section{Conclusion}

The results of the present study demonstrated that secretion of adiponectin leptin, resistin and visfatin is altered in subjects with T2DM clearly suggesting that they may be related to obesity, hypertension and cardiovascular disease. These adipocytokines may be an important link between increased fat mass, insulin resistance, disorders of lipid and glucose metabolism and endothelial dysfunction in diabetic patients. It may concluded that in addition to $\mathrm{HbA} 1 \mathrm{c} \%$, serum visfatin may be suggested the most prominent biomarker adipokinein glucophage treated T2DM while leptinthe most prominent one in obese BMI $\geq 30$ but the studied metabolic disorders diseases did not affect serum levels of adiponectin, resistin and apelin. It could be said that high level of visfatin contributed in the regulation of serum glucose in treated T2DM and may maintain the normal levels of serumim munoglobulins and complement factors C3 and C4. It also seems that visfatin was a potential supporter to insulin actions in glucophage treated T2DM. The higher levels of leptin, visfatin, resistin and the lower level of adiponectin and apelin in obese diabetics, suggested that different adipocytokines may play different roles in insulin resistance which may increase susceptibility of obese T2DM subjects to more complications.

\section{Future Directions}

Obesity is associated with an array of health problems including insulin resistance and type 2 diabetes, fatty liver disease, atherosclerosis, airway diseases, degenerative disorders and various types of cancer. The understanding of the pathogenesis of obesity and its metabolic sequel has advanced significantly over the past decades. Environmental factors, such as sedentary lifestyle and increased calorie intake, in combination with an unfavorable genotype, are responsible for the epidemic of obesity. Excess visceral fat accumulation results in altered release 
of adipokines, leading to CNS mediated skeletal muscle and hepatic insulin resistance. Understanding of the diverse effects of distinct adipokines and the interactions between these bioactive mediators is still incomplete. Unraveling the pathophysiological roles of adipokines in obesity-induced diseases likely will result in new pharmacotherapeutic approaches. Future studies on these adipocytokines may shed new light on the prevention and treatment of T2DM and offer a new field for the development of novel drugs with which to alleviate insulin resistance and obesity.

\section{Acknowledgements}

This study was supported by grants from the Scientific Research Projects Commission of Qassim University.

\section{References}

[1] IDF (2011) Diabetes Atlas. 15th Edition, International Diabetes Federation (IDF). www.diabetesatlas.org

[2] Steppan, C.M., Bailey, S.T., Bhat, S., Brown, E.J., Banerjee, R.R., Wright, C.M., Patel, H.R., Ahima, R.S. and Lazar, M.A. (2001) The Hormone Resistin Links Obesity to Diabetes. Nature, 409, 307-312. http://dx.doi.org/10.1038/35053000

[3] Goldstein, B.J. (2002) Insulin Resistance as the Core Defect in Type 2 Diabetes Mellitus. The American Journal of Cardiology, 90, 3G-10G. http://dx.doi.org/10.1016/S0002-9149(02)02553-5

[4] Lempiainen, P., Mykkanen, L., Pyorala, K., Laakso, M. and Kuusisto, J. (1999) Insulin Resistance Syndrome Predicts Coronary Heart Disease Events in Elderly Nondiabetic Men. Circulation, 100, 123-128. http://dx.doi.org/10.1161/01.CIR.100.2.123

[5] Mlinar, B., Marc, J., Janez, A. and Pfeifer, M. (2007) Molecular Mechanisms of Insulin Resistance and Associated Diseases. Clinica Chimica Acta, 375, 20-35. http://dx.doi.org/10.1016/j.cca.2006.07.005

[6] Ingelsson, E., Arnlov, J., Lind, L. and Sundstrom, J. (2006) Metabolic Syndrome and Risk for Heart Failure in MiddleAged Men. Heart, 92, 1409-1413. http://dx.doi.org/10.1136/hrt.2006.089011

[7] Lakka, H.M., Laaksonen, D.E., Lakka, T.A., Niskanen, L.K., Kumpusalo, E., et al. (2002) The Metabolic Syndrome and Total and Cardiovascular Disease Mortality in Middle-Aged Men. JAMA, 288, 2709-2716. http://dx.doi.org/10.1001/jama.288.21.2709

[8] Kahn, S.E., Hull, R.L. and Utzschneider, K.M. (2006) Mechanisms Linking Obesity to Insulin Resistance and Type 2 Diabetes. Nature, 444, 840-846. http://dx.doi.org/10.1038/nature05482

[9] Weiss, R., Dziura, J., Burgert, T.S., et al. (2004) Obesity and the Metabolic Syndrome in Children and Adolescents. The New England Journal of Medicine, 350, 2362-2374. http://dx.doi.org/10.1056/NEJMoa031049

[10] Ouchi, N., Kihara, S., Funahashi, T., Matsuzawa, Y. and Walsh, K. (2003) Obesity, Adiponectin and Vascular Inflammatory Disease. Current Opinion in Lipidology, 14, 561-566. http://dx.doi.org/10.1097/00041433-200312000-00003

[11] Koerner, A., Kratzsch, J. and Kiess, W. (2005) Adipocytokines: Leptin—The Classical, Resistin—The Controversical, Adiponectin-The Promising, and More to Come. Best Practice \& Research Clinical Endocrinology \& Metabolism, 19, 525-546. http://dx.doi.org/10.1016/j.beem.2005.07.008

[12] Tilg, H. and Moschen, A.R. (2006) Adipocytokines: Mediators Linking Adipose Tissue, Inflammation and Immunity. Nature Reviews Immunology, 6, 772-783. http://dx.doi.org/10.1038/nri1937

[13] Matsuzawa, Y. (2005) Adipocytokines and Metabolic Syndrome. Seminars in Vascular Medicine, 5, 34-39. http://dx.doi.org/10.1055/s-2005-871744

[14] Rabin, K.R., Kamari, Y., Avni, I., Grossman, E. and Sharabi, Y. (2005) Adiponectin: Linking the Metabolic Syndrome to Its Cardiovascular Consequences. Expert Review of Cardiovascular Therapy, 3, 465-471. http://dx.doi.org/10.1586/14779072.3.3.465

[15] Guzik, T.J., Korbut, R. and Adamek-Guzik, T. (2003) Nitric Oxide and Superoxide in Inflammation and Immune Regulation. Journal of Physiology and Pharmacology, 54, 469-487.

[16] Klaus, S. (2004) Adipose Tissue as a Regulator of Energy Balance. Current Drug Targets, 5, 241-250. http://dx.doi.org/10.2174/1389450043490523

[17] Matsuzawa, Y. (2010) Adiponectin: A Key Player in Obesity Relate Disorders. Current Pharmaceutical Design, 16, 1896-1901. http://dx.doi.org/10.2174/138161210791208893

[18] Falcão-Pires, I., Castro-Chaves, P., Miranda-Silva, D., Lourenço, A.P. and Leite-Moreira, A.F. (2012) Physiological, Pathological and Potential Therapeutic Roles of Adipokines. Drug Discovery Today, 17, 880-889. http://dx.doi.org/10.1016/j.drudis.2012.04.007 
[19] Pelleymounter, M.A., Cullen, M.J., Baker, M.B., Hecht, R., Winters, D., Boone, T., et al. (1995) Effects of the Obese Gene Product on Body Weight Regulation in ob/ob Mice. Science, 269, 540-543. http://dx.doi.org/10.1126/science.7624776

[20] Lee, G.H., Proenca, R., Montez, J.M., Carroll, K.M., Darvishzadeh, J.G., Lee, J.I., et al. (1996) Abnormal Splicing of the Leptin Receptor in Diabetic Mice. Nature, 379, 632-635. http://dx.doi.org/10.1038/379632a0

[21] Saladin, R., De Vos, P., Guerre-Millo, M., Leturque, A., Girard, J., Staels, B., et al. (1995) Transient Increase in Obese Gene Expression after Food Intake or Insulin Administration. Nature, 377, 527-529. http://dx.doi.org/10.1038/377527a0

[22] Geffroy, S., De Vos, P., Staels, B., Duban, B., Auwerx, J. and de Martinville, B. (1995) Localization of the Human OB Gene (OBS) to Chromosome 7q32 by Fluorescence in Situ Hybridization. Genomics, 28, 603-604. http://dx.doi.org/10.1006/geno.1995.1201

[23] Brzozowski, T., Konturek, P.C., Konturek, S.J., Brzozowska, I. and Pawlik, T. (2005) Role of Prostaglandins in Gastroprotection and Gastric Adaptation. Journal of Physiology and Pharmacology, 56, 33-55.

[24] Nawrot-Porabka, K., Jaworek, J., Leja-Szpak, A., Palonek, M., Szklarczyk, J., Konturek, S.J., et al. (2004) Leptin Is Able to Stimulate Pancreatic Enzyme Secretion via Activation of Duodeno-Pancreatic Reflex and CCK Release. Journal of Physiology and Pharmacology, 55, 47-57.

[25] Konturek, P.C., Brzozowski, T., Burnat, G., Kwiecien, S., Pawlik, T., Hahn, E.G., et al. (2004) Role of Brain-Gut Axis in Healing of Gastric Ulcers. Journal of Physiology and Pharmacology, 55, 179-192.

[26] Konturek, S.J., Konturek, J.W., Pawlik, T. and Brzozowski, T. (2004) Brain-Gut Axis and Its Role in the Control of Food Intake. Journal of Physiology and Pharmacology, 55, 137-154.

[27] Konturek, S.J., Pepera, J., Zabielski, K., Konturek, P.C., Pawlik, T., Szlachcic, A., et al. (2003) Brain-Gut Axis in Pancreatic Secretion and Appetite Control. Journal of Physiology and Pharmacology, 54, 293-317.

[28] Farooqi, I.S., Matarese, G., Lord, G.M., Keogh, J.M., Lawrence, E., Agwu, C., et al. (2002) Beneficial Effects of Leptin on Obesity, T Cell Hyporesponsiveness, and Neuroendocrine/Metabolic Dysfunction of Human Congenital Leptin Deficiency. Journal of Clinical Investigation, 110, 1093-1103. http://dx.doi.org/10.1172/JCI0215693

[29] Montague, C.T., Farooqi, I.S., Whitehead, J.P., Soos, M.A., Rau, H., Wareham, N.J., et al. (1997) Congenital Leptin Deficiency Is Associated with Severe Early-Onset Obesity in Humans. Nature, 387, 903-908. http://dx.doi.org/10.1038/43185

[30] Zoladz, J.A., Konturek, S.J., Duda, K., Majerczak, J., Sliwowski, Z., Grandys, M., et al. (2005) Effect of Moderate Incremental Exercise, Performed in Fed and Fasted State on Cardio-Respiratory Variables and Leptin and Ghrelin Concentrations in Young Healthy Men. Journal of Physiology and Pharmacology, 56, 63-85.

[31] Considine, R.V., Sinha, M.K., Heiman, M.L., Kriauciunas, A., Stephens, T.W., Nyce, M.R., et al. (1996) Serum Immunoreactive-Leptin Concentrations in Normal-Weight and Obese Humans. New England Journal of Medicine, 334, 292-295. http://dx.doi.org/10.1056/NEJM199602013340503

[32] Kim, S., Whelan, J., Claycombe, K., Reath, D.B. and Moustaid-Moussa, N. (2002) Angiotensin II Increases Leptin Secretion by ${ }_{3} \mathrm{~T}_{3}-\mathrm{L}_{1}$ and Human Adipocytes via a Prostaglandin-Independent Mechanism. Journal of Nutrition, 132, $1135-1140$

[33] Ran, J., Hirano, T., Fukui, T., Kageyama, H., Okada, K. and Adachi, M. (2006) Angiotensin II Infusion Decreases Plasma Adiponectin Level via Its Type 1 Receptor in Rats: An Implication for Hypertension-Related Insulin Resistance. Metabolism, 55, 478-488. http://dx.doi.org/10.1016/j.metabol.2005.10.009

[34] Kaminski, T., Smolinska, N., Gajewska, A., Siawrys, G., Okrasa, S., Kochman, K., et al. (2006) Leptin and Long Form of Leptin Receptor Genes Expression in the Hypothalamus and Pituitary during the Luteal Phase and Early Pregnancy in Pigs. Journal of Physiology and Pharmacology, 57, 95-108.

[35] Beltowski, J., Marciniak, A. and Wojcicka, G. (2004) Leptin Decreases Renal Medullary Na(+), K(+)-ATPase Activity through Phosphatidylinositol 3-Kinase Dependent Mechanism. Journal of Physiology and Pharmacology, 57, 391-407.

[36] Jaworek, J., Bonior, J., Konturek, S.J., Bilski, J., Szlachcic, A. and Pawlik, W.W. (2003) Role of Leptin in the Control of Postprandial Pancreatic Enzyme Secretion. Journal of Physiology and Pharmacology, 57, 591-602.

[37] Stallmeyer, B., Pfeilschifter, J. and Frank, S. (2001) Systemically and Topically Supplemented Leptin Fails to Reconstitute a Normal Angiogenic Response during Skin Repair in Diabetic ob/ob mice. Diabetologia, 44, 471-479. Http://Dx.Doi.Org/10.1007/S001250051645

[38] Kougias, P., Chai, H., Lin, P.H., Yao, Q., Lumsden, A.B. and Chen, C. (2005) Effects of Adipocyte-Derived Cytokines on Endothelial Functions: Implication of Vascular Disease. Journal of Surgical Research, 126, 121-129. http://dx.doi.org/10.1016/j.jss.2004.12.023

[39] Schwartz, M.W., Woods, S.C., Porte Jr., D., Seeley, R.J. and Baskin, D.G. (2000) Central Nervous System Control of Food Intake. Nature, 404, 661-671. 
[40] Friedman, J.M. and Halaas, J.L. (1998) Leptin and the Regulation of Body Weight in Mammals. Nature, 395, 763-770. http://dx.doi.org/10.1038/27376

[41] Kaur, T. and Zhang, Z.F. (2005) Obesity, Breast Cancer and the Role of Adipocytokines. Asian Pacific Journal of Cancer Prevention, 6, 547-552.

[42] Kubota, N., Terauchi, Y., Yamauchi, T., Kubota, T., Moroi, M., Matsui, J., et al. (2002) Disruption of Adiponectin Causes Insulin Resistance and Neointimal Formation. Journal of Biological Chemistry, 277, 25863-25866. http://dx.doi.org/10.1074/jbc.C200251200

[43] Xu, A., Yin, S., Wong, L., Chan, K.W. and Lam, K.S. (2004) Adiponectin Ameliorates Dyslipidemia Induced by the Human Immunodeficiency Virus Protease Inhibitor Ritonavir in Mice. Endocrinology, 145, 487-494. http://dx.doi.org/10.1210/en.2003-1140

[44] Yoon, M.J., Lee, G.Y., Chung, J.J., Ahn, Y.H., Hong, S.H. and Kim, J.B. (2006) Adiponectin Increases Fatty Acid Oxidation in Skeletal Muscle Cells by Sequential Activation of AMP-Activated Protein Kinase, p38 Mitogen-Activated Protein Kinase, and Peroxisome Proliferator-Activated Receptor Alpha. Diabetes, 55, 2562-2570. http://dx.doi.org/10.2337/db05-1322

[45] Yamauchi, T., Kamon, J., Ito, Y., Tsuchida, A., Yokomizo, T., Kita, S., et al. (2003) Cloning of Adiponectin Receptors That Mediate Antidiabetic Metabolic Effects. Nature, 423, 762-769. http://dx.doi.org/10.1038/nature01705

[46] Qi, Y., Takahashi, N., Hileman, S.M., Patel, H.R., Berg, A.H., Pajvani, U.B., Scherer, P.E. and Ahima, R.S. (2004) Adiponectin Acts in the Brain to Decrease Body Weight. Nature Medicine, 10, 524-529.

http://dx.doi.org/10.1038/nm1029

[47] Neumeier, M., Weigert, J., Schaffler, A., Wehrwein, G., Müller-Ladner, U., Schölmerich, J., et al. (2006) Different Effects of Adiponectin Isoforms in Human Monocytic Cells. Journal of Leukocyte Biology, 79, 803-808. http://dx.doi.org/10.1189/jlb.0905521

[48] Wasim, H., Al-Daghri, N.M., Chetty, R., McTernan, P.G., Barnett, A.H. and Kumar, S. (2006) Relationship of Serum Adiponectin and Resistin to Glucose Intolerance and Fat Topography in South-Asians. Cardiovascular Diabetology, 5, 10. http://dx.doi.org/10.1186/1475-2840-5-10

[49] Fain, J.N. (2006) Release of Interleukins and Other Inflammatory Cytokines by Human Adipose Tissue Is Enhanced in Obesity and Primarily Due to the Nonfat Cells. Vitamins \& Hormones, 74, 443-477. http://dx.doi.org/10.1016/S0083-6729(06)74018-3

[50] Bastard, J.P., Maachi, M., Lagathu, C., Kim, M.J., Caron, M., Vidal, H., et al. (2006) Recent Advances in the Relationship between Obesity, Inflammation, and Insulin Resistance. European Cytokine Network, 17, 4-12.

[51] Fukuhara, A., Matsuda, M., Nishizawa, M., Segawa, K., Tanaka, M., Kishimoto, K., et al. (2005) Visfatin: A Protein Secreted by Visceral Fat That Mimics the Effects of Insulin. Science, 307, 426-430. http://dx.doi.org/10.1126/science.1097243

[52] Beltowski, J. (2006) Apelin and Visfatin: Unique "Beneficial” Adipokines Upregulated in Obesity? Medical Science Monitor, 12, RA112-RA119.

[53] Haider, D.G., Schaller, G., Kapiotis, S., Maier, C., Luger, A. and Wolzt, M. (2006) The Release of the Adipocytokine Visfatin Is Regulated by Glucose and Insulin. Diabetologia, 49, 1909-1914. http://dx.doi.org/10.1007/s00125-006-0303-7

[54] Revollo, J.R., Korner, A., Mills, K.F., Satoh, A., Wang, T., Garten, A., et al. (2007) Nampt/PBEF/Visfatin Regulates Insulin Secretion in Beta Cells as a Systemic NAD Biosynthetic Enzyme. Cell Metabolism, 6, 363-375.

[55] Brown, J.E., Onyango, D.J., Ramanjaneya, M., Conner, A.C., Patel, S.T., Dunmore, S.J., et al. (2010) Visfatin Regulates Insulin Secretion, Insulin Receptor Signalling and mRNA Expression of Diabetes-Related Genes in Mouse Pancreatic Beta-Cells. Journal of Molecular Endocrinology, 44, 171-178. http://dx.doi.org/10.1677/JME-09-0071

[56] Lan, J., Chen, X., Wang, S., Wanga, S., Zhang, X., Wu, K., et al. (2011) The Relationship between Visfatin and HOMA-IR in Hypertensive Patients, and the Effect of Antihypertensive Drugs on Visfatin and HOMA-IR in Hypertensive Patients with Insulin Resistance. Diabetes Research and Clinical Practice, 94, 71-76. http://dx.doi.org/10.1016/j.diabres.2011.05.039

[57] Straburzynska-Lupa, A., Nowak, A., Pilaczynska-Szczesniak, L., Straburzyńska-Migaj, E., Romanowski, W., Karolkiewicz, J., et al. (2010) Visfatin, Resistin, hsCRP and Insulin Resistance in Relation to Abdominal Obesity in Women with Rheumatoid Arthritis. Clinical and Experimental Rheumatology, 28, 19-24.

[58] Tatemoto, K., Takayama, K., Zou, M.X., Kumaki, I., Zhang, W., et al. (2001) The Novel Peptide Apelin Lowers Blood Pressure via a Nitric Oxide-Dependent Mechanism. Regulatory Peptides, 99, 87-92. http://dx.doi.org/10.1016/S0167-0115(01)00236-1

[59] Boucher, J., Masri, B., Daviaud, D., Gesta, S., Guigne, C., et al. (2005) Apelin, a Newly Identified Adipokine Up-Regulated by Insulin and Obesity. Endocrinology, 146, 1764-1771. http://dx.doi.org/10.1210/en.2004-1427 
[60] El Messari, S., Iturrioz, X., Fassot, C., De Mota, N., Roesch, D., et al. (2004) Functional Dissociation of Apelin Receptor Signaling and Endocytosis: Implications for the Effects of Apelin on Arterial Blood Pressure. Journal of Neurochemistry, 90, 1290-1301. http://dx.doi.org/10.1111/j.1471-4159.2004.02591.x

[61] Tatemoto, K., Hosoya, M., Habata, Y., Fujii, R., Kakegawa, T., et al. (1998) Isolation and Characterization of a Novel Endogenous Peptide Ligand for the Human APJ Receptor. Biochemical and Biophysical Research Communications, 251, 471-476. http://dx.doi.org/10.1006/bbrc.1998.9489

[62] Castan-Laurell, I., Dray, C., Knauf, C., Kunduzova, O. and Valet, P. (2012) Apelin, a Promising Target for Type 2 Diabetes Treatment? Trends in Endocrinology and Metabolism, 23, 234-241. http://dx.doi.org/10.1016/j.tem.2012.02.005

[63] Attané, C., Foussal, C., Le Gonidec, S., Benani, A., Daviaud, D., Wanecq, E., et al. (2012) Apelin Treatment Increases Complete Fatty Acid Oxidation, Mitochondrial Oxidative Capacity, and Biogenesis in Muscle of Insulin-Resistant Mice. Diabetes, 61, 310-320. http://dx.doi.org/10.2337/db11-0100

[64] Yue, P., Jin, H., Xu, S., Aillaud, M., Deng, A.C., et al. (2011) Apelin Decreases Lipolysis via G $\mathrm{G}_{\mathrm{q}}$, G, and AMPK-Dependent Mechanisms. Endocrinology, 152, 59-68. http://dx.doi.org/10.1210/en.2010-0576

[65] Attané, C., Daviaud, D., Dray, C., Dusaulcy, R., Masseboeuf, M., Prévot, D., et al. (2011) Apelin Stimulates Glucose Uptake but Not Lipolysis in Human Adipose Tissue ex Vivo. Journal of Molecular Endocrinology, 46, 21-28. http://dx.doi.org/10.1677/JME-10-0105

[66] Guo, L., Li, Q., Wang, W., Yu, P., Pan, H., Li, P., et al. (2009) Apelin Inhibits Insulin Secretion in Pancreatic BetaCells by Activation of PI3-Kinase-Phosphodiesterase 3B. Endocrine Research, 34, 142-154. http://dx.doi.org/10.3109/07435800903287079

[67] Soriguer, F., Garrido-Sanchez, L., Garcia-Serrano, S., Garcia-Almeida, J.M., Garcia-Arnes, J., et al. (2009) Apelin Levels Are Increased in Morbidly Obese Subjects with Type 2 Diabetes Mellitus. Obesity Surgery, 19, 1574-1580. http://dx.doi.org/10.1007/s11695-009-9955-y

[68] Dray, C., Debard, C., Jager, J., Disse, E., Daviaud, D., Martin, P., et al. (2010) Apelin and APJ Regulation in Adipose Tissue and Skeletal Muscle of Type 2 Diabetic Mice and Humans. American Journal of Physiology: Endocrinology and Metabolism, 298, E1161-E1169. http://dx.doi.org/10.1152/ajpendo.00598.2009

[69] Erdem, G., Dogru, T., Tasci, I., Sonmez, A. and Tapan, S. (2008) Low Plasma Apelin Levels in Newly Diagnosed Type 2 Diabetes Mellitus. Experimental and Clinical Endocrinology \& Diabetes, 116, 289-292. http://dx.doi.org/10.1055/s-2007-1004564

[70] Zhang, Y., Shen, C., Li, X., Ren, G., Fan, X., Ren, F., et al. (2009) Low Plasma Apelin in Newly Diagnosed Type 2 Diabetes in Chinese People. Diabetes Care, 32, e150. http://dx.doi.org/10.2337/dc09-1146

[71] Meral, C., Tascilar, E., Karademir, F., Tanju, I.A., Cekmez, F., Metin, O., et al. (2010) Elevated Plasma Levels of Apelin in Children with Type 1 Diabetes Mellitus. Journal of Pediatric Endocrinology and Metabolism, 23, 497-502. http://dx.doi.org/10.1515/jpem.2010.081

[72] Telejko, B., Kuzmicki, M., Wawrusiewicz-Kurylonek, N., Szamatowicz, J., Nikolajuk, A., Zonenberg, A., et al. (2010) Plasma Apelin Levels and Apelin/APJ mRNA Expression in Patients with Gestational Diabetes Mellitus. Diabetes Research and Clinical Practice, 87, 176-183. http://dx.doi.org/10.1016/j.diabres.2009.10.018

[73] Kouyama, K., Miyake, K., Zenibayashi, M., Hirota, Y., Teranishi, T., Tamori, Y., et al. (2007) Association of Serum MCP-1 Concentration and MCP-1 Polymorphism with Insulin Resistance in Japanese Individuals with Obese Type 2 Diabetes. Kobe Journal of Medical Sciences, 53, 345-354.

[74] Suzuki, T., Imai, J., Yamada, T., Ishigaki, Y., Kaneko, K., Uno, K., et al. (2011) Interleukin-6 Enhances Glucose-Stimulated Insulin Secretion from Pancreatic Beta-Cells: Potential Involvement of the PLC-IP3-Dependent Pathway. Diabetes, 60, 537-547.

[75] Besedovsky, H.O. and Del Rey, A. (2010) Interleukin-1 Resets Glucose Homeostasis at Central and Peripheral Levels: Relevance for Immunoregulation. Neuroimmunomodulation, 17, 139-141. http://dx.doi.org/10.1159/000258707

[76] Enomoto, T., Ohashi, K., Shibata, R., Higuchi, A., Maruyama, S., Izumiya, Y., et al. (2011) Adipolin/C1qdc2/CTRP12 Protein Functions as an Adipokine That Improves Glucose Metabolism. Journal of Biological Chemistry, 286, 3455234558.

[77] Choi, J.H., Rhee, E.J., Kim, K.H., Woo, H.Y., Lee, W.Y. and Sung, K.C. (2011) Plasma Omentin-1 Levels Are Reduced in Non-Obese Women with Normal Glucose Tolerance and Polycystic Ovary Syndrome. European Journal of Endocrinology, 165, 789-796. http://dx.doi.org/10.1530/EJE-11-0375

[78] Lamers, D., Famulla, S., Wronkowitz, N., Hartwig, S., Lehr, S., Ouwens, D.M., et al. (2011) Dipeptidyl Peptidase 4 Is a Novel Adipokine Potentially Linking Obesity to the Metabolic Syndrome. Diabetes, 60, 1917-1925. http://dx.doi.org/10.2337/db10-1707

[79] El-Hazmi, M.A.F., Warsy, A.S., Al-Swailem, A.R., Al-Swailem, A.M. and Sulaimani, R. (1998) Diabetes Mellitus as a Health Problem in Saudi Arabia. Eastern Mediterranean Health Journal, 4, 58-67. 
[80] Al-Nozha, M.M., Al-Maatouq, M.A., Al-Mazrou, Y.Y., Al-Harthi, S.S., Arafah, M.R., Khalil, M.Z., Khan, N.B., Al-Khadra, A., Al-Marzouki, K., Nouh, M.S., Abdullah, M., Attas, O., Al-Shahid, M.S. and Al-Mobeireek, A. (2009) Diabetes Mellitus in Saudi Arabia. Saudi Medical Journal, 25, 1603-1610. King Fahd University of Petroleum \& Minerals. http://www.kfupm.edu.sa

[81] Gokalp, D., Bahceci, M., Ozmen, S., Arikan, S., Tuzcu, A. and Danıs, R. (2008) Adipocyte Volumes and Levels of Adipokines in Diabetes and Obesity. Diabetes \& Metabolic Syndrome: Clinical Research \& Reviews, 2, 253-258. http://dx.doi.org/10.1016/j.dsx.2008.07.001

[82] Gualillo, O., González-Juanatey, J.R. and Lago, F. (2007) The Emerging Role of Adipokines as Mediators of Cardiovascular Function: Physiologic and Clinical Perspectives. Trends in Cardiovascular Medicine, 17, 275-283. http://dx.doi.org/10.1016/j.tcm.2007.09.005

[83] Esteghamati, A., Alamdari, A., Zandieh, A., Elahi, S., Khalilzadeh, O., Nakhjavani, M. and Meysamie, A. (2011) Serum Visfatin Is Associated with Type 2 Diabetes Melitus Independent of Insulin Resistance and Obesity. Diabetes Research and Clinical Practice, 91, 154-158. http://dx.doi.org/10.1016/j.diabres.2010.11.003

[84] Alghasham, A.A. and Barakat, Y.A. (2008) Serum Visfatin and Its Relation to Insulin Resistance and Inflammation in Type 2 Diabetic Patients with and without Macroangiopathy. Saudi Medical Journal, 29, 185-192.

[85] Chang, Y.H., Chang, D.M., Lin, K.C., Shin, S.J. and Lee, Y.J. (2011) Visfatin in Overweight/Obesity, Type 2 Diabetes Mellitus, Insulin Resistance, Metabolic Syndrome and Cardiovascular Diseases: A Meta-Analysis and Systemic Review. Diabetes/Metabolism Research and Reviews, 27, 515-527. http://dx.doi.org/10.1002/dmrr.1201

[86] El-Mesallamy, H.O., Kassem, D.H., El-Demerdash, E. and Amin, A.I. (2011) Vaspin and Visfatin/Nampt Are Interesting Interrelated Adipokines Playing a Role in the Pathogenesis of Type 2 Diabetes Mellitus. Metabolism, 60, 63-70. http://dx.doi.org/10.1016/j.metabol.2010.04.008

[87] Sandeep, S., Velmurugan, K., Deepa, R. and Mohan, V. (2007) Serum Visfatin in Relation to Visceral Fat, Obesity, and Type 2 Diabetes Mellitus in Asian Indians. Metabolism, 56, 565-570. http://dx.doi.org/10.1016/j.metabol.2006.12.005

[88] Shaker, O., El-Shehaby, A., Zakaria, A., Mostafa, N., Talaat, S., Katsiki, N. and Mikhailidis, D.P. (2011) Plasma Visfatin and Retinol Binding Protein-4 Levels in Patients with Type 2 Diabetes Mellitus and Their Relationship to Adiposity and Fatty Liver. Clinical Biochemistry, 44, 1457-1463. http://dx.doi.org/10.1016/j.clinbiochem.2011.08.1148

[89] Meshkani, R. and Adeli, K. (2009) Hepatic Insulin Resistance, Metabolic Syndrome and Cardiovascular Disease. Clinical Biochemistry, 42, 1331-1346. http://dx.doi.org/10.1016/j.clinbiochem.2009.05.018

[90] Zhu, J., Schott, M., Liu, R., Liu, C., Shen, B., Wang, Q., Mao, X., Xu, K., Wu, X., Schinner, S., Papewalis, C., Scherbaum, W.A. and Liu, C. (2008) Intensive Glycemic Control Lowers Plasma Visfatin Levels in Patients with Type 2 Diabetes. Hormone and Metabolic Research, 40, 801-805. http://dx.doi.org/10.1055/s-0028-1082040

[91] Bloomgarden, Z.T. (2002) New Insights in Obesity. Diabetes Care, 25, 789-795. http://dx.doi.org/10.2337/diacare.25.4.789

[92] Chen, M.P., Chung, F.M., Chang, D.M., Tsai, J.C.R., Huang, H.F., Shin, S.J., et al. (2006) Elevated Plasma Level of Visfatin/Pre-B Cell Colony-Enhancing Factor in Patients with Type 2 Diabetes Mellitus. Journal of Clinical Endocrinology \& Metabolism, 91, 295-299. http://dx.doi.org/10.1210/jc.2005-1475

[93] Miao-Pei, C., et al. (2006) Elevated Plasma Level of Visfatin/Pre-B Cell Colony Enhancing Factor in Patients with Type 2 Diabetes Mellitus. Journal of Clinical Endocrinology \& Metabolism, 91, 295-299. http://dx.doi.org/10.1210/jc.2005-1475

[94] Kamiñska, A., Kopczyńska, E., Bronisz, A., Zmudzińska, M., Bieliński, M., Borkowska, A., et al. (2010) An Evaluation of Visfatin Levels in Obese Subjects. Endokrynologia Polska, 61, 169-173.

[95] Tasci, I., Erdem, G., Ozgur, G., Tapan, S., Dogru, T., Genc, H., et al. (2009) LDL-Cholesterol Lowering Increases Plasma Apelin in Isolated Hypercholesterolemia. Atherosclerosis, 204, 222-228. http://dx.doi.org/10.1016/j.atherosclerosis.2008.08.030

[96] Li, L., Yang, G., Li, Q., Tang, Y., Yang, M., Yang, H., et al. (2006) Changes and Relations of Circulating Visfatin, Apelin, and Resistin Levels in Normal, Impaired Glucose Tolerance, and Type 2 Diabetic Subjects. Experimental and Clinical Endocrinology \& Diabetes, 114, 544-548. http://dx.doi.org/10.1055/s-2006-948309

[97] Dray, C., Knauf, C., Daviaud, D., Waget, A., Boucher, J., et al. (2008) Apelin Stimulates Glucose Utilization in Normal and Obese Insulin-Resistant Mice. Cell Metabolism, 8, 437-445. http://dx.doi.org/10.1016/j.cmet.2008.10.003

[98] Horiuchi, Y., Fujii, T., Kamimura, Y. and Kawashima, K. (2003) The Endogenous, Immunologically Active Peptide Apelin Inhibits Lymphocytic Cholinergic Activity during Immunological Responses. Journal of Neuroimmunology, 144, 46-52. http://dx.doi.org/10.1016/j.jneuroim.2003.08.029

[99] Ranjana, S., Fisch, G., Teague, B., Tamborlane, W.V., Banyas, B., Allen, K., et al. (2002) Prevalence of Impaired Glucose Tolerance among Children and Adolescents with Marked Obesity. New England Journal of Medicine, 346, 802810. http://dx.doi.org/10.1056/NEJMoa012578 
[100] Lu, H.L., Wang, H.W., Wen, Y., Zhang, M.X. and Lin, H.H. (2006) Roles of Adipocyte Derived Hormone Adiponectin and Resistin in Insulin Resistance of Type 2 Diabetes. World Journal of Gastroenterology, 12, 1747-1751.

[101] Mojiminiyi, O.A. and Abdella, N.A. (2007) Associations of Resistin with Inflammation and Insulin Resistance in Patients with Type 2 Diabetes Mellitus. Scandinavian Journal of Clinical \& Laboratory Investigation, 67, 215-225. http://dx.doi.org/10.1080/00365510601032532

[102] Kusminski, C.M., McTernan, P.G. and Kumar, S. (2005) Role of Resistin in Obesity, Insulin Resistance and Type II Diabetes. Clinical Science, 109, 243-256. http://dx.doi.org/10.1042/CS20050078

[103] Ouchi, N., Parker, J.L., Lugus, J.J. and Walsh, K. (2011) Adipokines in Inflammation and Metabolic Disease. Nature Reviews Immunology, 11, 85-97. http://dx.doi.org/10.1038/nri2921

[104] Sahu, A. (2011) Intracellular Leptin-Signaling Pathways in Hypothalamic Neurons: The Emerging Role of Phosphatidylinositol-3 Kinase-Phosphodesterase-3 B-Camp Pathway. Neuroendocrinology, 93, 201-210. http://dx.doi.org/10.1159/000326785

[105] Mataresse, G., La Cava, A., Sanna, V., Howard, J.K., Lord, G.M., Carravetta, C., Fontana, S., Lechler, R.I., Bloom, S.R. and De Placido, G. (2000) Increased Leptin Levels in Serum and Peritoneal Fluid of Patients with Pelvic Endometriosis. Journal of Clinical Endocrinology \& Metabolism, 85, 2483-2487.

[106] Matarese, G., Sanna, V., Lechler, R.I., Sarvetnick, N., Fontana, S., Zappacosta, S., et al. (2002) Leptin Accelerates Autoimmune Diabetes in Female NOD Mice. Diabetes, 51, 1356-1361. http://dx.doi.org/10.2337/diabetes.51.5.1356

[107] Reilly, M.P., Iqbal, N., Schutta, M., Wolfe, M.L., Scally, M., Localio, A.R., Rader, D.J. and Kimmel, S.E. (2004) Plasma Leptin Levels Are Associated with Coronary Atherosclerosis in Type 2 Diabetes. Journal of Clinical Endocrinology \& Metabolism, 89, 3872-3878. http://dx.doi.org/10.1210/jc.2003-031676

[108] Kamińska, A., Kopczyńska, E., Bronisz, A., Żmudzińska, M., Bieliński, M., Borkows, A., et al. (2010) An Evaluation of Visfatin Levels in Obese Subjects. Endokrynologia Polska, 61, 169-173.

[109] Wannamethee, S.G., Tchernova, J., Whincup, P., Lowe, G.D., Kelly, A., Rumley, A., Wallace, A.M. and Sattar, N. (2007) Plasma Leptin: Associations with Metabolic, Inflammatory and Haemostatic Risk Factors for Cardiovascular Disease. Atherosclerosis, 191, 418-426. http://dx.doi.org/10.1016/j.atherosclerosis.2006.04.012

[110] Stefanović, A., Kotur-Stevuljević, J., Spasić, S., Bogavac-Stanojević, N. and Bujisić, N. (2008) The Influence of Obesity on the Oxidative Stress Status and the Concentration of Leptin in Type 2 Diabetes Mellitus Patients. Diabetes Research and Clinical Practice, 79, 156-163. http://dx.doi.org/10.1016/j.diabres.2007.07.019

[111] Abdella, N.A., Mojiminiyi, O.A., Moussa, M.A., Zaki, M., Al Mohammedi, H., Al Ozairi, E.S. and Al Jebely, S. (2005) Plasma Leptin Concentration in Patients with Type 2 Diabetes: Relationship to Cardiovascular Disease Risk Factors and Insulin Resistance. Diabetic Medicine, 22, 278-285. http://dx.doi.org/10.1111/j.1464-5491.2004.01405.x

[112] Asakawa, H., Tokunaga, K. and Kawakami, F. (2001) Relationship of Leptin Level with Metabolic Disorders and Hypertension in Japanese Type 2 Diabetes Mellitus Patients. Journal of Diabetes and its Complications, 15, 57-62. http://dx.doi.org/10.1016/S1056-8727(00)00145-8

[113] Thorand, B., Zierer, A., Baumert, J., Meisinger, C., Herder, C. and Koenig, W. (2010) Associations between Leptin and the Leptin/Adiponectin Ratio and Incident Type 2 Diabetes in Middle-Aged Men and Women: Results from the MONICA/KORA Augsburg Study 1984-2002. Diabetic Medicine, 27, 1004-1011. http://dx.doi.org/10.1111/j.1464-5491.2010.03043.x

[114] Maenhaut, N. and van de Voorde, J. (2011) Regulation of Vascular Tone by Adipocytes. BMC Medicine, 16, 9-25.

[115] Snehalatha, C., Mukesh, B., Simon, M., Viswanathan, V., Haffner, S.M. and Ramachandran, A. (2003) Plasma Adiponectin Is an Independent Predictor of Type 2 Diabetes in Asian Indians. Diabetes Care, 26, 3226-3229. http://dx.doi.org/10.2337/diacare.26.12.3226

[116] Li, S., Shin, H.J., Ding, E.L. and van Dam, R.M. (2009) Adiponectin Levels and Risk of Type 2 Diabetes: A Systematic Review and Meta-Analysis. The Journal of the American Medical Association, 302, 179-188. http://dx.doi.org/10.1001/jama.2009.976

[117] Lautamäki, R., Rönnemaa, T., Huupponen, R., Lehtimäki, T., Iozzo, P., Airaksinen, K.E., Knuuti, J. and Nuutila, P. (2007) Low Serum Adiponectin Is Associated with High Circulating Oxidized Low-Density Lipoprotein in Patients with Type 2 Diabetes Mellitus and Coronary Artery Disease. Metabolism, 56, 881-886. http://dx.doi.org/10.1016/j.metabol.2007.01.018

[118] Matsuzawa, Y., Funahashi, T. and Nakamura, T. (1999) Molecular Mechanism of Metabolic Syndrome X: Contribution of Adipocytokines Adipocyte-Derived Bioactive Substances. Annals of the New York Academy of Sciences, 892, 146-154.

[119] Kern, P.A., Di Gregorio, G.B., Lu, T., Rassouli, N. and Ranganathan, G. (2003) Adiponectin Expression from Human Adipose Tissue: Relation to Obesity, Insulin Resistance, and Tumor Necrosis Factor- $\alpha$ Expression. Diabetes, 52, 1779-1785. http://dx.doi.org/10.2337/diabetes.52.7.1779 
[120] Okamoto, Y., Kihara, S., Ouchi, N., Nishida, M., Arita, Y., Kumada, M., Ohashi, K., Sakai, N., Shimomura, I., Kobayashi, H., Terasaka, N., Inaba, T., Funahashi, T. and Matsuzawa, Y. (2002) Adiponectin Reduces Atherosclerosis in Apolipoprotein E-Deficient Mice. Circulation, 106, 2767-2770. http://dx.doi.org/10.1161/01.CIR.0000042707.50032.19

[121] Spergel, J.M., Mizoguchi, E., Oettgen, H., Bhan, A.K. and Geha, R.S. (1999) Roles of $\mathrm{T}_{\mathrm{H} 1}$ and $\mathrm{T}_{\mathrm{H} 2}$ Cytokines in a Murine Model of Allergic Dermatitis. Journal of Clinical Investigation, 103, 1103-1111. http://dx.doi.org/10.1172/JCI5669

[122] Dubucquoi, S., Desreumaux, P., Janin, A., Klein, O., Goldman, M., Tavernir, J., Capron, A. and Capron, M. (1994) Interleukin 5 Synthesis by Eosinophils Association with Granules and Immunoglobulin Dependent Secretion. Journal of Experimental Medicine, 179, 703-708. http://dx.doi.org/10.1084/jem.179.2.703

[123] Matsuzawa, Y., Funashi, T., Kihara, S. and Shimomura, I. (2004) Adiponectin and Metabolic Syndrome. Arteriosclerosis, Thrombosis, and Vascular Biology, 24, 29-33. http://dx.doi.org/10.1161/01.ATV.0000099786.99623.EF

[124] Trujillo, M.E. and Scherer, P.E. (2005) Adiponectin Journey from an Adipocyte Secretory Protein to Biomarker of the Metabolic Syndrome. Journal of Internal Medicine, 257, 167-175. http://dx.doi.org/10.1111/j.1365-2796.2004.01426.x

[125] Halleux, C.N.M., Takahashi, M., Delporte, M.L., Detryc, R., Funahashi, T., Matsuzawa, Y. and Brichard, S.M. (2001) Secretion of Adiponectin and Regulation of apM1 Gene Expression in Human Visceral Adipose Tissue. Biochemical and Biophysical Research Communications, 288, 1102-1107. http://dx.doi.org/10.1006/bbrc.2001.5904

[126] Nagaev, I. and Smith, U. (2001) Insulin Resistance and Type 2 Diabetes Are Not Related to Resistin Expression in Human Fat Cells or Skeletal Muscle. Biochemical and Biophysical Research Communications, 285, 561-564. http://dx.doi.org/10.1006/bbrc.2001.5173

[127] Habib, S.S. (2012) Serum Resistin Levels in Patients with Type 2 Diabetes Mellitus and Its Relationship with Body Composition. Saudi Medical Journal, 33, 495-499.

[128] Gharibeh, M.Y., Al Tawallbeh, G.M., Abboud, M.M., Radaideh, A., Alhader, A.A. and Khabour, O.F. (2010) Correlation of Plasma Resistin with Obesity and Insulin Resistance in Type 2 Diabetic Patients. Diabetes \& Metabolism, 6, 443-449. http://dx.doi.org/10.1016/j.diabet.2010.05.003

[129] Sommer, G., Garten, A., Petzold, S., Beck-Sickinger, A.G., Bluher, M., Stumvoll, M., et al. (2008) Visfatin/PBEF/Nampt: Structure, Regulation and Potential Function of a Novel Adipokine. Clinical Science, 115, 13-23.

[130] Rego-Filho, E.A., Mello, S.F., Omuro, A.M. and Loli, J.O. (2003) Simultaneous Onset of Steroid-Sensitive Nephrotic Syndrome and Type 1 Diabetes. Jornal de Pediatria, 79, 557-560.

[131] Mantzoros, C., Petridou, E., Dessypris, N., Chavelas, C., Dalamaga, M., Alexe, D.M., et al. (2004) Adiponectin and Breast Cancer Risk. Journal of Clinical Endocrinology \& Metabolism, 89, 1102-1107. http://dx.doi.org/10.1210/jc.2003-031804 